\title{
Antigen Presentation by Vascular Cells
}

\author{
Jordan S. Pober ${ }^{*}$, Jonathan Merola ${ }^{2}$, Rebecca Liu' ${ }^{1}$ and Thomas D. Manes ${ }^{1}$ \\ 'Department of Immunobiology, Yale School of Medicine, New Haven, CT, United States, ${ }^{2}$ Department of Surgery, \\ Yale School of Medicine, New Haven, CT, United States
}

Antigen presentation by cells of the vessel wall may initiate rapid and localized memory immune responses in peripheral tissues. Peptide antigens displayed on major histocompatibility complex (MHC) molecules on the surface of endothelial cells (ECs) can be recognized by $T$ cell receptors on circulating effector memory $T$ cells $\left(T_{E M}\right)$, triggering both transendothelial migration and activation. The array of co-stimulatory receptors, adhesion molecules, and cytokines expressed by ECs serves to modulate $T$ cell activation responses. While the effects of these interactions vary among species, vascular beds, and vascular segments within the same tissue, they are capable of triggering allograft rejection without direct involvement of professional antigen-presenting cells and

OPEN ACCESS

Edited by:

Pooja Arora,

Albert Einstein College of

Medicine, United States

Reviewed by:

Alice Sijts,

Utrecht University, Netherlands Kristen J. Radford,

The University of Queensland, Australia

*Correspondence: Jordan S. Pober jordan.pober@yale.edu

Specialty section:

This article was submitted to Antigen Presenting Cell Biology, a section of the journal Frontiers in Immunology

Received: 10 October 2017 Accepted: 14 December 2017 Published: 22 December 2017

Citation:

Pober JS, Merola J, Liu R and Manes TD (2017) Antigen Presentation by Vascular Cells.

Front. Immunol. 8:1907. doi: 10.3389/fimmu.2017.01907 may play a similar role in host defense against infections and in autoimmunity. Once across the endothelium, extravasating $T_{E M}$ then contact mural cells of the vessel wall, including pericytes or vascular smooth muscle cells, which may also present antigens and provide signals that further regulate $T$ cell responses. Collectively, these interactions provide an unexplored opportunity in which targeting of vascular cells can be used to modulate immune responses. In organ transplantation, targeting ECs with siRNA to reduce expression of $\mathrm{MHC}$ molecules may additionally mitigate perioperative injuries by preformed alloantibodies, further reducing the risk of graft rejection. Similarly, genetic manipulation of vascular cells to minimize antigen-dependent responses can be used to increase perfusion of tissue engineered organs without triggering rejection.

Keywords: endothelial cells, pericytes, smooth muscle cells, effector memory $\mathrm{T}$ cells, regulatory $\mathrm{T}$ cells, transendothelial migration

\section{INTRODUCTION}

Primary adaptive immune responses are initiated when foreign antigens are presented to naïve T cells by "professional" myeloid antigen-presenting cells (APCs), such as dendritic cells (DCs) residing in secondary lymphoid organs. In response to antigen recognition, naïve $\mathrm{T}$ cells both expand and differentiate into effector T cells and various memory T cell subsets. Memory T cells persist long after antigen clearance, and in response to reappearance of the same antigen, rapidly initiate secondary (memory) responses directly at sites where antigen has reappeared (1). Memory T cells may reside within the tissues $\left(\mathrm{T}_{\mathrm{RM}}\right)$ or circulate as effector memory $\mathrm{T}$ cells $\left(\mathrm{T}_{\mathrm{EM}}\right)$ that are recruited to peripheral tissues following "activation" of the local microvasculature induced by inflammatory cytokines, pathogen-associated or damage-associated molecular patterns (2). Activated endothelial cells (ECs) lining the local vasculature express adhesion molecules and elaborate chemokines that capture and promote transmigration of $\mathrm{T}_{\mathrm{EM}}(3,4)$. Alternatively, $\mathrm{T}_{\mathrm{EM}}$ may be directly recruited 
by antigens presented by ECs (5). Extravasating $\mathrm{T}_{\mathrm{EM}}$ must then interact with the mural cells that support the ECs, namely pericytes (PCs) in microvessels or vascular smooth muscle cells (VSMCs) in larger vessels, that may also present antigens that modulate $\mathrm{T}_{\mathrm{EM}}$ responses $(6,7)$. Here, we review the topic of antigen presentation by these vascular cell types.

\section{ANTIGEN PRESENTATION BY ECs}

\section{Major Histocompatibility Complex (MHC) Molecules}

The capacity of cells to form and display peptide antigens complexed to MHC molecules, class I to CD8+ T lymphocytes and class II to CD4+ T lymphocytes, is a prerequisite for antigen presentation. Peptide antigens presented by ECs may be self-derived, though the same peptide-MHC complex may be tolerogenic or pro-inflammatory in response to the milieu in which lymphocyte encounter occurs (8). Microvascular ECs in humans and most other mammals basally express both class I and class II MHC molecules in vivo $(9,10)$. However, the abundance of MHC expression by ECs differs among vascular segments and can vary in response to environmental signals (11). Unlike other mammals, mouse and rat ECs do not basally express class II molecules in vivo $(12,13)$, a significant consideration when extrapolating results from murine models to human pathology.

Human ECs reduce their level of class I and ablate class II MHC expression in cell culture. Class I MHC expression can be restored by type 1 interferons (IFN- $\alpha$ or $-\beta$ ), type 2 interferon (IFN- $\gamma$ ), or tumor necrosis factors (both TNF- $\alpha$ or lymphotoxin- $\alpha$ ), whereas class II MHC is induced only by IFN- $\gamma(14,15)$. In vivo, basal expression of class I MHC is lost on arterial ECs in knockout mice lacking IFN- $\gamma$ or the IFN- $\gamma$ receptor (16). In canines, treatment with cyclosporine to inhibit cytokine production similarly results in loss of basal class II MHC molecule expression on arterial ECs (17). The expression of both classes of MHC molecules requires concomitant expression of several proteins required for peptide generation and loading. In cultured human ECs, these proteins are coordinately regulated by the same cytokines that induce class I and class II $\operatorname{MHC}(18,19)$.

\section{Co-stimulatory Signals}

Effective antigen presentation to T cells by an APC additionally requires antigen-independent signals delivered by cell surface co-stimulators that engage $\mathrm{T}$ cell counter-receptors and signal to augment and complement T cell receptor (TCR) signals $(20,21)$. The specific co-stimulators required for effective $\mathrm{T}$ cell activation differ for naïve and memory $\mathrm{T}$ cells and among memory $\mathrm{T}$ cell subsets. The co-stimulators B7.1 (CD80) and B7.2 (CD86) that engage $\mathrm{T}$ cell CD28 appear indispensable for activation of naïve $\mathrm{T}$ cells though expression of these molecules on ECs has been controversial. While some reports note the presence of B7.1 and B7.2 in human EC cultures (22-27), several other reports were unable to produce these findings (28-32). The absence of these molecules is consistent with the inability of human ECs to activate allogeneic naïve $\mathrm{T}$ cells $(30,33)$. However, cultured human
ECs can activate allogeneic memory $\mathrm{T}$ cells using other costimulators and may do so with comparable or greater proficiency than professional myeloid APCs $(30,33,34)$. The most potent co-stimulator of memory $\mathrm{T}$ cells on human ECs is lymphocyte function-associated antigen (LFA)-3 (CD58), which engages $\mathrm{CD} 2$, a counter-receptor expressed more highly on $\mathrm{T}_{\mathrm{EM}}$ than on naïve $\mathrm{T}$ cells (33). Other important co-stimulators expressed basally or inducibly on human ECs which engage cognate receptors on activated memory $\mathrm{T}$ cells are summarized in Table $\mathbf{1}$.

Endothelial cells may also display signals that dampen $\mathrm{T}_{\mathrm{EM}}$ activation, referred to as negative co-stimulators or checkpoint inhibitors (Table 1). Counter-receptors for negative co-stimulatory are expressed predominantly on activated T cells. CTLA-4 (CD152), the first described inhibitory receptor, binds B7.1 and B7.2 with higher affinity than does CD28 $(44,45)$, but as noted above, these proteins have not been consistently observed on human ECs. IFN- $\gamma$ induces mouse ECs to express PD-L1 (CD274) and human ECs to express both PD-L1 and PD-L2 (CD273) (35, 46), negative co-stimulators that engage PD-1 (CD279) expressed on activated $\mathrm{T}_{\mathrm{EM}}$. Other $\mathrm{T}$ cell inhibitory receptors include TIGIT, TIM3, and LAG3 (37), but it is not yet known if any EC proteins deliver negative co-stimulatory signals through these molecules.

TABLE 1 | Cell surface proteins mediating antigen presentation by endothelial cells (ECS) to $T_{E M}$.

\begin{tabular}{|c|c|c|c|}
\hline EC molecule & $\begin{array}{l}\mathrm{T}_{\mathrm{EM}} \\
\text { counter-receptor }\end{array}$ & Function & Reference \\
\hline $\begin{array}{l}\text { Major histocompatibility } \\
\text { complex (MHC) class I }\end{array}$ & $\begin{array}{l}\text { T cell receptor } \\
(\mathrm{TCR}), \mathrm{CD} 8\end{array}$ & Activation & (9) \\
\hline MHC class $\|$ & TCR, CD4 & Activation & (10) \\
\hline B7.1 (CD80), B7.2 (CD86)a & CD28 & Costimulation & $(22-27)$ \\
\hline LFA-3 (CD58) & CD2 & Costimulation & (33) \\
\hline ICOS-L (CD275) & $\begin{array}{l}\text { ICOS (CD278), } \\
\text { CD28 }\end{array}$ & Costimulation & (33) \\
\hline O×40-L (CD252) & Ox40 (CD134) & Costimulation & (33) \\
\hline 4-1BB-L (CD137L) & 4-1BB (CD137) & Costimulation & (33) \\
\hline CD40L (CD154) & CD40 & Costimulation & (33) \\
\hline CD40 & CD40L (CD154) & Unknown & (23) \\
\hline $\begin{array}{l}\text { PD-L1 (CD274), PD-L2 } \\
\text { (CD273) }\end{array}$ & PD-1 & Inhibition & (35) \\
\hline B7.1 (CD80), B7.2 (CD86) & CTLA-4 & Inhibition & $(22-27)$ \\
\hline CD155 & TIGIT & Inhibition? & (36) \\
\hline Galectin-9, CEACAM-1 & TIM3 & Inhibition? & $(37,38)$ \\
\hline Unknown & LAG3 (CD223) & Inhibition? & (37) \\
\hline E-Selectin (CD62E) & $\begin{array}{l}\text { ESL-1, ESL-2, } \\
\text { CLA-1 }\end{array}$ & $\begin{array}{l}\text { Tethering and } \\
\text { rolling }\end{array}$ & (3) \\
\hline P-Selectin (CD62P) & PSGL-1 & $\begin{array}{l}\text { Tethering and } \\
\text { rolling }\end{array}$ & (39) \\
\hline ICAM-1 & $\begin{array}{l}\text { LFA-1 (CD11a/ } \\
\text { CD18) }\end{array}$ & $\begin{array}{l}\text { Firm adhesion, } \\
\text { diapedesis, } \\
\text { costimulation }\end{array}$ & $(3,40,41)$ \\
\hline VCAM-1 & VLA-4 & $\begin{array}{l}\text { Rolling, firm } \\
\text { adhesion, } \\
\text { diapedesis }^{c}\end{array}$ & $(42)$ \\
\hline PECAM-1 (CD31) & Unknown & Diapedesis & (43) \\
\hline MIC2 (CD99) ${ }^{\mathrm{C}}$ & MIC2 (CD99) & Diapedesis & $(4)$ \\
\hline $\begin{array}{l}\text { PVR (CD155), Nectin-2 } \\
(C D 112)^{c}\end{array}$ & $\begin{array}{l}\text { Tactile (CD96), } \\
\text { DNAM (CD226) }\end{array}$ & Diapedesis & (4) \\
\hline
\end{tabular}

aNot consistently found on human ECs.

${ }^{b}$ Humans only.

${ }^{c} C D 4 T_{E M}$ only. 


\section{Adhesion Molecules}

In addition to peptide-MHC and co-stimulatory recognition, effective activation of $\mathrm{T}$ cells requires stable attachment to the APCs for several minutes. Molecules that contribute to $\mathrm{T}$ cell adhesion to ECs are summarized in Table 1. At sites of inflammation, initial tethering and subsequent rolling (propelled by flowing blood) of $\mathrm{T}$ cells is largely mediated by interactions of selectins expressed on activated ECs with glycosylated ligands on $\mathrm{T}$ lymphocytes. $\mathrm{T}$ cell recognition of chemokines displayed on the EC lumen triggers T cell spreading, firm attachment and migration to EC junctions. These higher affinity interactions are mediated by $\mathrm{T}$ cell integrins (47). Notably, $\mathrm{T}_{\mathrm{EM}}$ express high levels of LFA-1 (CD11a/CD18) and very late activation antigen (VLA)-4 (CD49d/CD29), two key integrins that specifically bind to proteins that are highly expressed on cytokine-activated human ECs, namely intercellular adhesion molecule (ICAM)-1 and vascular cell adhesion molecule (VCAM)-1, respectively (48). High affinity integrin binding requires both TCR signals and "tugging" of the integrin as the T cell is being pushed by flowing blood (49). In their high affinity state, these integrins enable $\mathrm{T}_{\mathrm{EM}}$ to firmly attach to activated microvascular ECs resisting detachment by blood flow. Engagement of LFA-1 integrin on T lymphocytes can stabilize mRNA transcripts of pro-inflammatory genes, implicating a dual role for these molecules in both $\mathrm{T}$ cell activation and adhesion $(40,41)$. Other human EC proteins engage counter receptors on $\mathrm{T}_{\mathrm{EM}}$ during the process of transendothelial migration (diapedesis), though whether these molecules influence TCR signaling is currently unknown.

\section{Cytokine Signals}

Cytokines produced by an activated T cell, by its APC, or by a bystander cell, provide a third class of signal that can influence the magnitude of a T cell response (50). ECs can be stimulated to release a number of active cytokines, but secreted molecules will be rapidly removed by blood flow. The effects of flow may be overcome by displaying cytokines bound to the EC surface. Many chemokines bound to the EC surface via the glycocalyx or via non-signaling receptors can activate attached leukocytes $(51,52)$. Although its method of attachment is unknown, interleukin (IL)- $1 \alpha$ can be displayed on the plasma membrane of human ECs and signal to T cells to increase their activation (53).

\section{Mechanisms of Allopresentation}

Because $\mathrm{T}_{\mathrm{EM}}$ specific for a given protein antigen are rare, even after expansion from naïve precursors, human responses are typically evaluated in vitro shortly after vaccination or by using polyclonal activators, superantigens, or non-self alloantigens. Alloantigen responses arise from cross-reacting $\mathrm{T}_{\mathrm{EM}}$ generated from naïve $\mathrm{T}$ cells activated in response to prior infections (54). Cultured human ECs can activate resting alloreactive CD8+ $\mathrm{T}_{\mathrm{EM}}$, measured as cytokine production or proliferation (34), and the latter response is enhanced by addition of exogenous IL-2, normally provided in vivo by activated CD4+ $\mathrm{T}_{\mathrm{EM}}$ (55). Although exogenous protein antigens are typically presented to CD4+ T cells as peptides bound to class II MHC molecules, professional APCs can "cross-present" to CD8+ T cells by loading such peptides on to class I MHC molecules. Mouse ECs also "crosspresent" antigen (56-58), but this has not been demonstrated in humans. However, human ECs may acquire intact class I MHC peptide complexes from other cells and then present these to $\mathrm{T}$ cells, a pathway of alloantigen presentation referred to as "crossdressing" or "semi-direct presentation" (59).

Cultured human ECs can stimulate alloreactive CD8+ $\mathrm{T}_{\mathrm{CM}}$ or $\mathrm{T}_{\mathrm{EM}}$, but not naïve $\mathrm{T}$ cells, to differentiate into cytotoxic $\mathrm{T}$ lymphocytes (CTL) (60). Interestingly, many of these CTL appear specific for ECs that share class I MHC alleles with the ECs used for stimulation but will not lyse B cells expressing the same alleles (61). This may represent a requirement for EC-derived peptides, differences in peptide processing, or a requirement of EC-specific adhesive ligands or co-stimulators. Cultured human ECs, induced to express class II MHC molecules by pretreatment with IFN- $\gamma$, effectively activate CD4 $+\mathrm{T}_{\mathrm{CM}}$ and $\mathrm{T}_{\mathrm{EM}}(34)$. In contrast, cultured mouse ECs, similarly induced to express class II MHC molecules, cannot activate resting CD4+ T cells to exhibit effector functions, but have been reported to activate (or induce) CD4+ T cells with regulatory functions (62). These differences are unexplained, but again raise caution when extrapolating observations from mouse experiments to human settings. In contrast, mouse ECs, which typically express B7.1, can activate naïve allogeneic CD8+ T cells in culture (63) and initiate allograft rejection in vivo in the absence of graft-derived professional APCs (64). In the case of allografts, $\mathrm{T}_{\mathrm{RM}}$ are graftderived so antigen presentation to circulating host $\mathrm{T}$ cells by graft ECs or DCs is required to initiate chemokine-mediated T cell recruitment and vigorous rejection (65).

\section{Lymphocyte Transendothelial Migration}

Cell culture experiments using superantigen have revealed that both $\mathrm{CD} 4+$ and $\mathrm{CD} 8+\mathrm{T}_{\mathrm{EM}}$ that recognize antigens on the apical surface of human microvascular ECs are induced to transmigrate through the EC barrier (66). Morphologically, the initial $\mathrm{T}$ cell response to antigen recognition on ECs appears similar to that which occurs during antigen presentation by professional APCs. $\mathrm{T}_{\mathrm{EM}}$ "round up," move their microtubule organizing center (MTOC) and cytosolic granules to the region between the nucleus and the EC surface (67). Despite flow, TCRengaged $\mathrm{T}_{\mathrm{EM}}$ remain attached to the $\mathrm{EC}$ for $30 \mathrm{~min}$ or more, i.e., sufficiently long enough for activation to occur. The attached $\mathrm{T}_{\mathrm{EM}}$ then extend a blunt cytosolic protrusion between adjacent ECs. Granules and the MTOC move into the protruding leading edge and the nucleus follows. Events in TCR-triggered transendothelial migration of human $\mathrm{T}_{\mathrm{EM}}$ are distinct from chemokine-mediated transendothelial migration in which $\mathrm{T}_{\mathrm{EM}}$ initially flatten out rather than rounding up and in which the MTOC and granules follow the nucleus between adjacent ECs in a trailing uropod rather than preceding the nucleus in a blunt protrusion. During TCR-triggered transendothelial migration, $\mathrm{CD} 4+\mathrm{T}_{\mathrm{EM}}$ discharge granules, releasing granzyme $\mathrm{A}$, the proteolytic activity of which is required for effective transmigration (67). In contrast, $\mathrm{CD} 8+\mathrm{T}_{\mathrm{EM}}$ transits through the EC monolayer without discharging their granules, which contain granzyme $\mathrm{B}$ and perforin in addition to granzyme A (66). The basis for this difference in granule release is unknown but protects EC 
from lysis. During transendothelial migration, CD4+ $\mathrm{T}_{\mathrm{EM}}$ also mobilize and interact with EC junctional proteins present in the lateral border recycling compartment, including PECAM-1 (CD31), CD99, polio virus receptor (CD155), and nectin-2 (CD112) (4), whereas CD8+ $\mathrm{T}_{\mathrm{EM}}$ bypass this requirement. Interestingly, mice lacking endothelial PECAM-1 are still able to recruit $\mathrm{CD} 8+\mathrm{T}_{\mathrm{EM}}$ and actually appear to do so more efficiently than wild-type mice (68). It is unclear if mouse ECs use antigen presentation to recruit $\mathrm{CD} 4+\mathrm{T}_{\mathrm{EM}}$. TCR-induced human $\mathrm{T}_{\mathrm{EM}}$ migration also involves reorganization of the actomyosin cytoskeleton, which is activated by TCR signaling through Vav and Rac, whereas chemokine-induced transmigration bypasses Vav and uses cdc42 instead of Rac to activate the cytoskeleton (69). While it is difficult to confirm that the same processes occur during human immune response in vivo, experiments in mice have demonstrated Vav-dependent TCR-based recruitment (70) as well as a distinction between TCR-and chemokine-initiated $\mathrm{T}$ cell recruitment based on only the latter showing pertussis toxin sensitivity (65).

\section{Activation of Regulatory T Cells}

Presentation of self-antigen linked to class II MHC molecules by ECs may be involved in the recruitment of $\mathrm{CD} 4+\mathrm{T}$ regulatory cells $\left(\mathrm{T}_{\mathrm{REG}}\right)$ to peripheral tissues (71). Under certain conditions, antigen presentation by human ECs may directly favor $\mathrm{T}_{\mathrm{REG}}$ activation. Specifically, unlike $\mathrm{T}_{\mathrm{EM}}$ activation, $\mathrm{T}_{\mathrm{REG}}$ proliferation is not inhibited by pretreatment of human EC with the mTOR inhibitor, rapamycin, thereby favoring $\mathrm{T}_{\mathrm{REG}}$ expansion (72). Blockade of endothelial secreted IL- 6 may promote the conversion of $\mathrm{T}_{\mathrm{H}} 17$ memory cells into $\mathrm{T}_{\mathrm{REG}}(73)$. It is unknown if recruitment of the recently described $\mathrm{CD} 4+\mathrm{T}$ peripheral helper cell $\left(\mathrm{T}_{\mathrm{PH}}\right)$ subset that can activate $\mathrm{B}$ cell responses in peripheral tissues can be recruited by EC antigen presentation (74). Finally, some specialized ECs may use antigen presentation to specifically tolerize $\mathrm{T}$ cells and inhibit immune responses. This has been described both for hepatic sinusoidal ECs and for lymphatic ECs in the mouse (75-77). However, the mechanisms of tolerance induction employed by these cells are not well understood, nor is it clear if the same mechanisms apply to human ECs lining such vessels.

\section{ANTIGEN PRESENTATION BY PCs AND VSMCs}

\section{Antigen Presentation by VSMCs}

$\mathrm{T}_{\mathrm{EM}}$ that enter tissues or the vessel wall (in the case of large blood vessels), will then encounter mural cells: PCs in microvessels or VSMCs in larger vessels. VSMCs express low levels of class I but not class II MHC molecules in situ; the abundance of MHC molecule expression by PCs in situ is unclear as resolving ECs and PCs by light microscopy is challenging. Under culture conditions human PCs or VSMCs, like cultured human ECs, similarly express low levels of class I and no detectable class II MHC but readily upregulate both class I and class II MHC molecules to levels comparable to those expressed on ECs in response to IFN- $\gamma(6,78)$. Moreover, following IFN- $\gamma$ treatment, both mural cell types appear able to present non-self alleles of class II MHC molecules to resting allogeneic CD4+ T cells, inducing expression of activation antigens on the T cell, such as CD69 and CD25. CD4+ T cells already activated by culture with IFN- $\gamma$-treated ECs, derived from the same donor as the VSMCs, can proliferate in response to IFN- $\gamma$-treated VSMCs (78). However, resting $\mathrm{T}_{\mathrm{EM}}$ directly isolated from peripheral blood will not proliferate in these cultures, but, such T cells cultured with VSMCs can be subsequently activated by culture with ECs from the same donor (i.e., they are not anergized). Failure of resting $\mathrm{T}$ cells to proliferate in response to allogeneic VSMCs may be attributed both to the expression of indolamine 2,3-dioxygenase (IDO), an enzyme that degrades tryptophan required for $\mathrm{T}$ cell anabolism and cell proliferation, and to the absence of ICOS-L, a critical co-stimulator $(79,80)$. In contrast, ECs readily express ICOS-L and significantly less IDO than VSMCs.

\section{Antigen Presentation by PCs}

Less has been reported about immunoregulation by human PCs. IFN- $\boldsymbol{\gamma}$-treated PCs express negative co-stimulatory receptors PD-L1 and PD-L2 at a higher level than do ECs. The role of PD-L1 or PD-L2 in inhibiting the activation of resting T cells, which typically lack PD-1, is largely unknown. Like VSMCs, IFN- $\gamma$-treated PCs express high levels of IDO that contributes to $\mathrm{T}$ cell inhibition (6). Importantly, CD4+ T cells cultured with allogeneic PCs do become clonally anergic, i.e., they are unable to subsequently respond to ECs from the same donor as the PCs. It is unknown how much of the inhibitory activities of PCs or VSMCs are induced by IFN- $\gamma$, utilized in these experiments to upregulate class II MHC molecules on the mural cells. There are likely to be differences among PCs (and VSMCs) from different species and among the mural cells found in different vascular beds within the same species. Cultured mouse PCs can express PD-L1 and are also immunoregulatory (81), but it has not been shown if mouse PCs present antigen. Despite the limited number of studies, the general conclusion is that mural cells present antigens in a manner that dampens ("regulate") $\mathrm{T}$ cell responses that are initiated by EC antigen presentation.

\section{THERAPEUTIC TARGETING OF ANTIGEN PRESENTATION BY VASCULAR CELLS}

The most compelling data regarding the antigen-presenting function of ECs has come from transplantation. As noted earlier, this may be explained by the fact that the $\mathrm{T}_{\mathrm{RM}}$ population within an allograft is derived from the donor and will, therefore, not respond to donor antigens as non-self. Consequently, the most relevant memory $\mathrm{T}$ cell population in transplant immunology is $\mathrm{T}_{\mathrm{EM}}$ which preferentially respond to antigens presented in the vascular lumen. While genetic manipulation of human organs for transplantation is not an immediate prospect, transient knockdown of gene expression by siRNA or anti-sense oligonucleotides in graft cells is much closer to clinical application, and a particularly attractive approach is to deliver a sustained source of siRNA to graft vessels ex vivo, prior to implantation, using hydrolyzable nanoparticle carriers (81). Relevant targets could include MHC 
molecules or co-stimulators such as LFA-3 that promote T cell activation or alternatively induction of negative co-stimulatory molecules in ECs or mural cells. Interestingly, rapamycin, which also could be delivered in nanoparticle carriers ex vivo, has been found to induce both PD-L1 and PD-L2 on ECs independently of IFN- $\gamma$, abrogating their capacity to activate $\mathrm{T}_{\mathrm{EM}}$ while retaining the capacity to activate $\mathrm{T}_{\mathrm{REG}}(72)$. The roles that vascular cells perform as APCs represent a largely untapped therapeutic target in these pathologic settings.

Human ECs have been implicated as APCs in other chronic disease states. For example, in type I diabetes, EC antigen presentation triggers T cell homing leading to islet cell destruction (27, 56), and in cerebral malaria, presentation of parasite antigens may activate CD8 effector cells leading to local edema and inflammation in the central nervous system (82). In both autoimmunity

\section{REFERENCES}

1. Woodland DL, Kohlmeier JE. Migration, maintenance and recall of memory T cells in peripheral tissues. Nat Rev Immunol (2009) 9(3):153-61. doi:10.1038/ nri2496

2. Sathaliyawala T, Kubota M, Yudanin N, Turner D, Camp P, Thome JJ, et al. Distribution and compartmentalization of human circulating and tissueresident memory T cell subsets. Immunity (2013) 38(1):187-97. doi:10.1016/j. immuni.2012.09.020

3. Manes TD, Pober JS. Antigen presentation by human microvascular endothelial cells triggers ICAM-1-dependent transendothelial protrusion by, and fractalkine-dependent transendothelial migration of, effector memory CD4+ T cells. J Immunol (2008) 180(12):8386-92. doi:10.4049/ jimmunol.180.12.8386

4. Manes TD, Pober JS. Identification of endothelial cell junctional proteins and lymphocyte receptors involved in transendothelial migration of human effector memory CD4+ T cells. J Immunol (2011) 186(3):1763-8. doi:10.4049/ jimmunol.1002835

5. Manes TD, Shiao SL, Dengler TJ, Pober JS. TCR signaling antagonizes rapid IP-10-mediated transendothelial migration of effector memory CD4+ T cells. J Immunol (2007) 178(5):3237-43. doi:10.4049/jimmunol.178.5.3237

6. Maier CL, Pober JS. Human placental pericytes poorly stimulate and actively regulate allogeneic CD4 T cell responses. Arterioscler Thromb Vasc Biol (2011) 31(1):183-9. doi:10.1161/ATVBAHA.110.217117

7. Tellides G, Tereb DA, Kirkiles-Smith NC, Kim RW, Wilson JH, Schechner JS, et al. Interferon-gamma elicits arteriosclerosis in the absence of leukocytes. Nature (2000) 403(6766):207-11. doi:10.1038/35003221

8. Rothermel AL, Wang Y, Schechner J, Mook-Kanamori B, Aird WC, Pober JS, et al. Endothelial cells present antigens in vivo. BMC Immunol (2004) 5:5. doi:10.1186/1471-2172-5-5

9. Daar AS, Fuggle SV, Fabre JW, Ting A, Morris PJ. The detailed distribution of HLA-A, B, C antigens in normal human organs. Transplantation (1984) 38(3):287-92. doi:10.1097/00007890-198409000-00018

10. Daar AS, Fuggle SV, Fabre JW, Ting A, Morris PJ. The detailed distribution of MHC Class II antigens in normal human organs. Transplantation (1984) 38(3):293-8. doi:10.1097/00007890-198409000-00019

11. Pober JS, Collins T, Gimbrone MA Jr, Libby P, Reiss CS. Inducible expression of class II major histocompatibility complex antigens and the immunogenicity of vascular endothelium. Transplantation (1986) 41(2):141-6. doi:10.1097/00007890-198602000-00001

12. Mestas J, Hughes CC. Of mice and not men: differences between mouse and human immunology. J Immunol (2004) 172(5):2731-8. doi:10.4049/ jimmunol.172.5.2731

13. Fabre JW. Rat kidney allograft model: was it all too good to be true? Transplantation (1982) 34(4):223-5. doi:10.1097/00007890-198210000-00016

14. Pober JS, Gimbrone MA Jr, Cotran RS, Reiss CS, Burakoff SJ, Fiers W, et al. Ia expression by vascular endothelium is inducible by activated $\mathrm{T}$ cells and by human gamma interferon. J Exp Med (1983) 157(4):1339-53. doi:10.1084/ jem.157.4.1339 and infection, however, the role of $\mathrm{T}_{\mathrm{EM}}$ may be redundant with that of $\mathrm{T}_{\mathrm{RM}}$, and may potentially limit the effects of blocking antigen presentation by ECs, though the effects of doing so remain to be investigated.

\section{AUTHOR CONTRIBUTIONS}

JSP authored the manuscript. JM, RL, and TM provided critical revisions to the manuscript.

\section{FUNDING}

This work was supported by grants and fellowships from the NIH: R01-HL051014 to JSP and TM; T32-DK007276 to JM; and F31-HL129563 and T32-GM0072905 to RL.

15. Lapierre LA, Fiers W, Pober JS. Three distinct classes of regulatory cytokines control endothelial cell MHC antigen expression. Interactions with immune gamma interferon differentiate the effects of tumor necrosis factor and lymphotoxin from those of leukocyte alpha and fibroblast beta interferons. J Exp Med (1988) 167(3):794-804.

16. Goes N, Urmson J, Hobart M, Halloran PF. The unique role of interferon-gamma in the regulation of MHC expression on arterial endothelium. Transplantation (1996) 62(12):1889-94. doi:10.1097/00007890-199612270-00036

17. Groenewegen G, Buurman WA, Jeunhomme GM, van der Linden CJ. Effect of cyclosporine on MHC class II antigen expression on arterial and venous endothelium in vitro. Transplantation (1985) 40(1):21-5. doi:10.1097/ 00007890-198507000-00005

18. Ma W, Lehner PJ, Cresswell P, Pober JS, Johnson DR. Interferon-gamma rapidly increases peptide transporter (TAP) subunit expression and peptide transport capacity in endothelial cells. J Biol Chem (1997) 272(26):16585-90. doi:10.1074/jbc.272.26.16585

19. Collins T, Korman AJ, Wake CT, Boss JM, Kappes DJ, Fiers W, et al. Immune interferon activates multiple class II major histocompatibility complex genes and the associated invariant chain gene in human endothelial cells and dermal fibroblasts. Proc Natl Acad Sci U S A (1984) 81(15):4917-21. doi:10.1073/pnas.81.15.4917

20. Hughes CC, Pober JS. Transcriptional regulation of the interleukin-2 gene in normal human peripheral blood $\mathrm{T}$ cells. Convergence of costimulatory signals and differences from transformed $\mathrm{T}$ cells. JBiol Chem (1996) 271(10):5369-77. doi:10.1074/jbc.271.10.5369

21. Croft M, Dubey C. Accessory molecule and costimulation requirements for CD4 T cell response. Crit Rev Immunol (1997) 17(1):89-118. doi:10.1615/ CritRevImmunol.v17.i1.40

22. Seino K, Azuma M, Bashuda H, Fukao K, Yagita H, Okumura K. CD86 (B70/B7-2) on endothelial cells co-stimulates allogeneic CD4+ T cells. Int Immunol (1995) 7(8):1331-7. doi:10.1093/intimm/7.8.1331

23. Jollow KC, Zimring JC, Sundstrom JB, Ansari AA. CD40 ligation induced phenotypic and functional expression of CD80 by human cardiac microvascular endothelial cells. Transplantation (1999) 68(3):430-9. doi:10.1097/00007890-199908150-00016

24. Prat A, Biernacki K, Becher B, Antel JP. B7 expression and antigen presentation by human brain endothelial cells: requirement for proinflammatory cytokines. J Neuropathol Exp Neurol (2000) 59(2):129-36. doi:10.1093/ jnen/59.2.129

25. Omari KI, Dorovini-Zis K. Expression and function of the costimulatory molecules B7-1 (CD80) and B7-2 (CD86) in an in vitro model of the human blood-brain barrier. J Neuroimmunol (2001) 113(1):129-41. doi:10.1016/ S0165-5728(00)00435-5

26. Tan PH, Chan C, Xue SA, Dong R, Ananthesayanan B, Manunta M, et al. Phenotypic and functional differences between human saphenous vein (HSVEC) and umbilical vein (HUVEC) endothelial cells. Atherosclerosis (2004) 173(2):171-83. doi:10.1016/j.atherosclerosis.2003.12.011

27. Lozanoska-Ochser B, Klein NJ, Huang GC, Alvarez RA, Peakman M. Expression of CD86 on human islet endothelial cells facilitates $\mathrm{T}$ cell 
adhesion and migration. J Immunol (2008) 181(9):6109-16. doi:10.4049/ jimmunol.181.9.6109

28. Murray AG, Khodadoust MM, Pober JS, Bothwell AL. Porcine aortic endothelial cells activate human T cells: direct presentation of MHC antigens and costimulation by ligands for human CD2 and CD28. Immunity (1994) 1(1):57-63. doi:10.1016/1074-7613(94)90009-4

29. Page C, Thompson C, Yacoub M, Rose M. Human endothelial stimulation of allogeneic T cells via a CTLA-4 independent pathway. Transpl Immunol (1994) 2(4):342-7. doi:10.1016/0966-3274(94)90013-2

30. Epperson DE, Pober JS. Antigen-presenting function of human endothelial cells. Direct activation of resting CD8 T cells. J Immunol (1994) 153(12):5402-12.

31. Denton MD, Geehan CS, Alexander SI, Sayegh MH, Briscoe DM. Endothelial cells modify the costimulatory capacity of transmigrating leukocytes and promote CD28-mediated CD4(+) T cell alloactivation. JExp Med (1999) 190(4):555-66. doi:10.1084/jem.190.4.555

32. Muczynski KA, Ekle DM, Coder DM, Anderson SK. Normal human kidney HLA-DR-expressing renal microvascular endothelial cells: characterization, isolation, and regulation of MHC class II expression. J Am Soc Nephrol (2003) 14(5):1336-48. doi:10.1097/01.ASN.0000061778.08085.9F

33. Shiao SL, McNiff JM, Pober JS. Memory T cells and their costimulators in human allograft injury. JImmunol (2005) 175(8):4886-96. doi:10.4049/ jimmunol.175.8.4886

34. Shiao SL, Kirkiles-Smith NC, Shepherd BR, McNiff JM, Carr EJ, Pober JS. Human effector memory CD4+ $\mathrm{T}$ cells directly recognize allogeneic endothelial cells in vitro and in vivo. J Immunol (2007) 179(7):4397-404. doi:10.4049/jimmunol.179.7.4397

35. Mazanet MM, Hughes CC. B7-H1 is expressed by human endothelial cells and suppresses T cell cytokine synthesis. J Immunol (2002) 169(7):3581-8. doi:10.4049/jimmunol.169.7.3581

36. Pende D, Bottino C, Castriconi R, Cantoni C, Marcenaro S, Rivera P, et al. PVR (CD155) and Nectin-2 (CD112) as ligands of the human DNAM-1 (CD226) activating receptor: involvement in tumor cell lysis. Mol Immunol (2005) 42(4):463-9. doi:10.1016/j.molimm.2004.07.028

37. Anderson AC, Joller N, Kuchroo VK. Lag-3, Tim-3, and TIGIT: co-inhibitory receptors with specialized functions in immune regulation. Immunity (2016) 44(5):989-1004. doi:10.1016/j.immuni.2016.05.001

38. Horst AK, Bickert T, Brewig N, Ludewig P, van Rooijen N, Schumacher U, et al. CEACAM1+ myeloid cells control angiogenesis in inflammation. Blood (2009) 113(26):6726-36. doi:10.1182/blood-2008-10-184556

39. Valenzuela NM, Mulder A, Reed EF. HLA class I antibodies trigger increased adherence of monocytes to endothelial cells by eliciting an increase in endothelial P-selectin and, depending on subclass, by engaging FcgammaRs. J Immunol (2013) 190(12):6635-50. doi:10.4049/jimmunol.1201434

40. Wang JG, Collinge M, Ramgolam V, Ayalon O, Fan XC, Pardi R, et al. LFA-1-dependent HuR nuclear export and cytokine mRNA stabilization in T cell activation. J Immunol (2006) 176(4):2105-13. doi:10.4049/jimmunol. 176.4.2105

41. Ramgolam VS, DeGregorio SD, Rao GK, Collinge M, Subaran SS, MarkovicPlese S, et al. T cell LFA-1 engagement induces HuR-dependent cytokine mRNA stabilization through a Vav-1, Rac1/2, p38MAPK and MKK3 signaling cascade. PLoS One (2010) 5(12):e14450. doi:10.1371/journal.pone. 0014450

42. Weber C, Springer TA. Interaction of very late antigen-4 with VCAM-1 supports transendothelial chemotaxis of monocytes by facilitating lateral migration. J Immunol (1998) 161(12):6825-34.

43. Manes TD, Hoer S, Muller WA, Lehner PJ, Pober JS. Kaposi's sarcomaassociated herpesvirus $\mathrm{K} 3$ and $\mathrm{K} 5$ proteins block distinct steps in transendothelial migration of effector memory CD4+ T cells by targeting different endothelial proteins. JImmunol (2010) 184(9):5186-92. doi:10.4049/ jimmunol.0902938

44. Walunas TL, Lenschow DJ, Bakker CY, Linsley PS, Freeman GJ, Green JM, et al. CTLA-4 can function as a negative regulator of $\mathrm{T}$ cell activation. Immunity (1994) 1(5):405-13. doi:10.1016/1074-7613(94)90071-X

45. Krummel MF, Allison JP. CD28 and CTLA-4 have opposing effects on the response of T cells to stimulation. JExp Med (1995) 182(2):459-65. doi:10.1084/jem.182.2.459

46. Rodig N, Ryan T, Allen JA, Pang H, Grabie N, Chernova T, et al. Endothelial expression of PD-L1 and PD-L2 down-regulates CD8+ T cell activation and cytolysis. Eur J Immunol (2003) 33(11):3117-26. doi:10.1002/ eji.200324270

47. Springer TA. Traffic signals for lymphocyte recirculation and leukocyte emigration: the multistep paradigm. Cell (1994) 76(2):301-14. doi:10.1016/0092-8674(94)90337-9

48. Carman CV, Martinelli R. T lymphocyte-endothelial interactions: emerging understanding of trafficking and antigen-specific immunity. Front Immunol (2015) 6:603. doi:10.3389/fimmu.2015.00603

49. Alon R, Dustin ML. Force as a facilitator of integrin conformational changes during leukocyte arrest on blood vessels and antigen-presenting cells. Immunity (2007) 26(1):17-27. doi:10.1016/j.immuni.2007.01.002

50. Curtsinger JM, Mescher MF. Inflammatory cytokines as a third signal for $\mathrm{T}$ cell activation. Curr Opin Immunol (2010) 22(3):333-40. doi:10.1016/j. coi.2010.02.013

51. Kuschert GS, Coulin F, Power CA, Proudfoot AE, Hubbard RE, Hoogewerf AJ, et al. Glycosaminoglycans interact selectively with chemokines and modulate receptor binding and cellular responses. Biochemistry (1999) 38(39):12959-68. doi:10.1021/bi990711d

52. Rot A. Contribution of Duffy antigen to chemokine function. Cytokine Growth Factor Rev (2005) 16(6):687-94. doi:10.1016/j.cytogfr.2005.05.011

53. Kurt-Jones EA, Fiers W, Pober JS. Membrane interleukin 1 induction on human endothelial cells and dermal fibroblasts. J Immunol (1987) 139(7):2317-24.

54. Espinosa JR, Samy KP, Kirk AD. Memory T cells in organ transplantation: progress and challenges. Nat Rev Nephrol (2016) 12(6):339-47. doi:10.1038/ nrneph.2016.9

55. Abrahimi P, Qin L, Chang WG, Bothwell AL, Tellides G, Saltzman WM, et al. Blocking MHC class II on human endothelium mitigates acute rejection. JCI Insight (2016) 1(1):e85293. doi:10.1172/jci.insight.85293

56. Savinov AY, Wong FS, Stonebraker AC, Chervonsky AV. Presentation of antigen by endothelial cells and chemoattraction are required for homing of insulin-specific CD8+ T cells. J Exp Med (2003) 197(5):643-56. doi:10.1084/ jem. 20021378

57. Bagai R, Valujskikh A, Canaday DH, Bailey E, Lalli PN, Harding CV, et al. Mouse endothelial cells cross-present lymphocyte-derived antigen on class I MHC via a TAP1- and proteasome-dependent pathway. J Immunol (2005) 174(12):7711-5. doi:10.4049/jimmunol.174.12.7711

58. Howland SW, Gun SY, Claser C, Poh CM, Renia L. Measuring antigen presentation in mouse brain endothelial cells ex vivo and in vitro. Nat Protoc (2015) 10(12):2016-26. doi:10.1038/nprot.2015.129

59. Smyth LA, Herrera OB, Golshayan D, Lombardi G, Lechler RI. A novel pathway of antigen presentation by dendritic and endothelial cells: Implications for allorecognition and infectious diseases. Transplantation (2006) 82(1 Suppl):S15-8. doi:10.1097/01.tp.0000231347.06149.ca

60. Dengler TJ, Pober JS. Human vascular endothelial cells stimulate memory but not naive $\mathrm{CD} 8+\mathrm{T}$ cells to differentiate into CTL retaining an early activation phenotype. J Immunol (2000) 164(10):5146-55. doi:10.4049/ jimmunol.164.10.5146

61. Biedermann BC, Pober JS. Human vascular endothelial cells favor clonal expansion of unusual alloreactive CTL. J Immunol (1999) 162(12): 7022-30.

62. Krupnick AS, Gelman AE, Barchet W, Richardson S, Kreisel FH, Turka LA, et al. Murine vascular endothelium activates and induces the generation of allogeneic CD4+25+Foxp3+ regulatory $\mathrm{T}$ cells. JImmunol (2005) 175(10):6265-70. doi:10.4049/jimmunol.175.10.6265

63. Kreisel D, Krupnick AS, Szeto W, Popma SH, Krasinskas AM, Rosengard B. Mouse vascular endothelium activates alloreactive CD8+ T lymphocytes in B-7 dependent fashion. J Heart Lung Transplant (2001) 20(2):249. doi:10.1016/ S1053-2498(00)00566-0

64. Kreisel D, Krupnick AS, Gelman AE, Engels FH, Popma SH, Krasinskas AM, et al. Non-hematopoietic allograft cells directly activate CD8+ T cells and trigger acute rejection: an alternative mechanism of allorecognition. Nat Med (2002) 8(3):233-9. doi:10.1038/nm0302-233

65. Walch JM, Zeng Q, Li Q, Oberbarnscheidt MH, Hoffman RA, Williams AL, et al. Cognate antigen directs CD8+ T cell migration to vascularized transplants. J Clin Invest (2013) 123(6):2663-71. doi:10.1172/JCI66722

66. Manes TD, Pober JS. Significant differences in antigen-induced transendothelial migration of human CD8 and CD4 T effector memory cells. Arterioscler Thromb Vasc Biol (2016) 36(9):1910-8. doi:10.1161/ATVBAHA. 116.308039 
67. Manes TD, Pober JS. Polarized granzyme release is required for antigen-driven transendothelial migration of human effector memory CD4 T cells. J Immunol (2014) 193(12):5809-15. doi:10.4049/jimmunol.1401665

68. Ma L, Cheung KC, Kishore M, Nourshargh S, Mauro C, Marelli-Berg FM. CD31 exhibits multiple roles in regulating T lymphocyte trafficking in vivo. J Immunol (2012) 189(8):4104-11. doi:10.4049/jimmunol.1201739

69. Manes TD, Pober JS. TCR-driven transendothelial migration of human effector memory CD4 T cells involves Vav, Rac, and myosin IIA. J Immunol (2013) 190(7):3079-88. doi:10.4049/jimmunol.1201817

70. David R, Ma L, Ivetic A, Takesono A, Ridley AJ, Chai JG, et al. T-cell receptorand CD28-induced Vav1 activity is required for the accumulation of primed T cells into antigenic tissue. Blood (2009) 113(16):3696-705. doi:10.1182/ blood-2008-09-176511

71. Fu H, Kishore M, Gittens B, Wang G, Coe D, Komarowska I, et al. Selfrecognition of the endothelium enables regulatory T-cell trafficking and defines the kinetics of immune regulation. Nat Commun (2014) 5:3436. doi:10.1038/ncomms4436

72. Wang C, Yi T, Qin L, Maldonado RA, von Andrian UH, Kulkarni S, et al. Rapamycin-treated human endothelial cells preferentially activate allogeneic regulatory T cells. J Clin Invest (2013) 123(4):1677-93. doi:10.1172/ JCI66204

73. Fogal B, Yi T, Wang C, Rao DA, Lebastchi A, Kulkarni S, et al. Neutralizing IL-6 reduces human arterial allograft rejection by allowing emergence of CD161+ CD4+ regulatory T cells. J Immunol (2011) 187(12):6268-80. doi:10.4049/ jimmunol.1003774

74. Rao DA, Gurish MF, Marshall JL, Slowikowski K, Fonseka CY, Liu Y, et al. Pathologically expanded peripheral T helper cell subset drives B cells in rheumatoid arthritis. Nature (2017) 542(7639):110-4. doi:10.1038/ nature20810

75. Limmer A, Ohl J, Kurts C, Ljunggren HG, Reiss Y, Groettrup M, et al. Efficient presentation of exogenous antigen by liver endothelial cells to CD8+ T cells results in antigen-specific T-cell tolerance. Nat Med (2000) 6(12):1348-54. doi:10.1038/82161

76. Tewalt EF, Cohen JN, Rouhani SJ, Engelhard VH. Lymphatic endothelial cells key players in regulation of tolerance and immunity. Front Immunol (2012) 3:305. doi:10.3389/fimmu.2012.00305
77. Hirosue S, Vokali E, Raghavan VR, Rincon-Restrepo M, Lund AW, CorthesyHenrioud P, et al. Steady-state antigen scavenging, cross-presentation, and CD8+ T cell priming: a new role for lymphatic endothelial cells. J Immunol (2014) 192(11):5002-11. doi:10.4049/jimmunol.1302492

78. Murray AG, Libby P, Pober JS. Human vascular smooth muscle cells poorly co-stimulate and actively inhibit allogeneic $\mathrm{CD} 4+\mathrm{T}$ cell proliferation in vitro. J Immunol (1995) 154(1):151-61.

79. Cuffy MC, Silverio AM, Qin L, Wang Y, Eid R, Brandacher G, et al. Induction of indoleamine 2,3-dioxygenase in vascular smooth muscle cells by interferon-gamma contributes to medial immunoprivilege. JImmunol (2007) 179(8):5246-54. doi:10.4049/jimmunol.179.8.5246

80. Zhang P, Manes TD, Pober JS, Tellides G. Human vascular smooth muscle cells lack essential costimulatory molecules to activate allogeneic memory T cells. Arterioscler Thromb Vasc Biol (2010) 30(9):1795-801. doi:10.1161/ ATVBAHA.109.200758

81. Cui J, Qin L, Zhang J, Abrahimi P, Li H, Li G, et al. Ex vivo pretreatment of human vessels with siRNA nanoparticles provides protein silencing in endothelial cells. Nat Commun (2017) 8(1):191. doi:10.1038/s41467017-00297-x

82. Jambou R, Combes V, Jambou MJ, Weksler BB, Couraud PO, Grau GE. Plasmodium falciparum adhesion on human brain microvascular endothelial cells involves transmigration-like cup formation and induces opening of intercellular junctions. PLoS Pathog (2010) 6(7):e1001021. doi:10.1371/ journal.ppat.1001021

Conflict of Interest Statement: The authors declare that the research was conducted in the absence of any commercial or financial relationships that could be construed as a potential conflict of interest.

Copyright ( 2017 Pober, Merola, Liu and Manes. This is an open-access article distributed under the terms of the Creative Commons Attribution License (CC BY). The use, distribution or reproduction in other forums is permitted, provided the original author(s) or licensor are credited and that the original publication in this journal is cited, in accordance with accepted academic practice. No use, distribution or reproduction is permitted which does not comply with these terms. 